\title{
Comparative Study of Basic Properties of Mud Prepared with Nigerian Local Clay and Mud Prepared with Foreign Clay: A Case Study of Abbi Clay Deposit
}

\author{
Okologume C. Wilfred ${ }^{1, a^{*}}$, Akinwumi E. Akinade ${ }^{2, b}$ \\ ${ }^{1,2}$ Department of Petroleum and Natural Gas Engineering, Federal University of Petroleum \\ Resources, Effurun, Nigeria \\ a*okologume.wilfred@fupre.edu.ng, bakinchem2003@yahoo.com
}

\begin{abstract}
Keywords: Rheological, Bentonite, Beneficiation, Drilling mud, America Petroleum Institute (API), Thixotropic, $\mathrm{pH}$
\end{abstract}

\begin{abstract}
This research study evaluates the performance of a local clay sample for drilling operations in Nigeria. The rheological and the thixotropic properties as well as other parameters of the Local clay mud was seen to have improved, but however, when beneficiated with chemical additives, there was an increase in the overall parameters of the Local mud samples, making it ideal for any industrial application as its parameters met with the stipulated standard specifications of API, OCDA. The rheological formulation of the locally sourced bentonite clay sample in substitute for the imported foreign bentonite clay was carried out by the comparative analysis of the parameters of the local mud with the stipulated API standard values to ascertain the level of compliance in drilling operation. The local mud $\mathrm{PH}$ values responded positively on beneficiation with $1.0 \mathrm{~g}$ of potash, the modification raised the mud $\mathrm{PH}$ value to fall within the standard range of 9.5 to 12.5 . The viscosity of the local mud was seen to be slightly below the standard requirement of $30 \mathrm{cp}$, but appreciated favorably to the standard requirement when beneficiated with $1.0 \mathrm{~g}$ of drispac. It was obvious that the prepared local mud sample parameters such as the sand percentage composition, power law index, density, marsh funnel viscosity, etc. met the minimum required specifications, while other few parameters such as the rheological properties, and $\mathrm{pH}$, needed some additive treatment for favorable comparison with the foreign clay mud properties. Therefore, the utilization of this clays for any industrial application will pose no harm to surface and subsurface facilities and will in turn represent a value added to the Nigeria's economy by the total prevention of the importation of high quality activated foreign bentonite clay.
\end{abstract}

\section{Introduction}

Research performed in the early $90^{\text {ee }}$ s by the Bureau of Mines of the U.S.A, showed that the sum of bentonite deposits in the world was about 1.36 billion tons, and the U.S.A. has more than $50.0 \%$ of the total ${ }^{[2]}$. It has been reported that the occurrence of more than 2 billion metric tons of bentonite reserve in Nigeria and the successful development of oil-well drilling mud from same. As of today, proven reserve has risen to more than 4 billion MT. The industrial demand of bentonite clays is as a result of the distinct characteristics of bentonite clays; thixotropic, swelling and absorption properties, have ${ }^{[4]}$. These properties have been attributed to the type of clay mineral, the nature of exchangeable cation(s) present in the bentonite and its cation exchange capacity ${ }^{[3] ;[8]}$. Bentonites continue to be the most widely used material for thickening fresh water base drilling fluid. Wyoming bentonite is the most commonly available commercial bentonite for drilling fluid applications. It is principally composed of sodium montmorillonite.

Bentonite use in the petroleum industry can be dated back to $1929^{[5]}$. Bentonite also known as gel, is composed primarily of smectite (API 10A, 2010). It contains not less than $85 \%$ of the clay mineral montmorillonite. The montmorillonite content of bentonite is the controlling factor in its effectiveness as an extender ${ }^{[6]}$. Bentonite is classified as sodium bentonite or calcium bentonite, depending on the dominant exchangeable cation. In fresh water, sodium bentonite is more reactive 
than calcium bentonite. In terms of performance bentonite is classified as "high yield" (Sodium bentonite) or "low yield" (Calcium Bentonite $)^{[9]}$.

The ability of the drilling mud to perform its function depends entirely on its viscosity ${ }^{[7]}$. Without viscosity, all weighting materials and drill cuttings would settle to the bottom of the hole as soon as circulation is stopped. Viscosity in drilling is a structure built within the water or oil phase which suspends solid material ${ }^{[10]}$.

Clay mineral studies of the Tertiary to Recent subsurface in Niger Delta have revealed occurrences of bentonite as well as other non-swelling kaolinitic clays. Since the Niger Delta opens to the sea, there is likelihood that the subsurface Niger Delta bentonite may be enriched in sodium from the saline seawater. Exploration efforts aimed at commercial exploitation are going on in several localities now, while some companies have actually started test mining. Table 1 below shows the location of bentonite deposits in Nigeria.

Table 1: Locations of Bentonite Deposits in Nigeria

\begin{tabular}{|c|c|c|c|c|}
\hline $\mathrm{S} / \mathrm{N}$ & STATE & LOCATION & ESTIMATED RESERVE & REMARKS \\
\hline 1. & Cross River & Ogurude & & $\begin{array}{l}\text { Need further } \\
\text { investigation. }\end{array}$ \\
\hline 2. & Akwa-Ibom & Itu & & \\
\hline 3. & Ebonyi & Ohaozara & & $\begin{array}{l}\text { Products of Asu } \\
\text { River Group Shale. }\end{array}$ \\
\hline 4. & Abia & $\begin{array}{l}\text { Arochukwu, Umuahia, } \\
\text { Bende, } \\
\text { IsiukwuatoIkwuano }\end{array}$ & $\begin{array}{l}\text { Proven/inferred reserves } \\
\text { is } 5.8-7.5 \text { mil. tones }\end{array}$ & $\begin{array}{l}\text { Most deposits } \\
\text { require further } \\
\text { investigation. }\end{array}$ \\
\hline 5. & Imo & Orlu, Isu, Oru, Okigwe & $\begin{array}{l}\text { Inferred reserve estimates } \\
\text { are } 5.8-7.5 \text { million tones }\end{array}$ & $\begin{array}{l}\text { Mining activities } \\
\text { are on in some of } \\
\text { the locations. }\end{array}$ \\
\hline 6. & Anambra & Awka & Not yet quantified & $\begin{array}{l}\text { Need for more } \\
\text { investigation. }\end{array}$ \\
\hline 7. & Gombe & $\begin{array}{l}\text { Akko, Gombe, Yamaltu- } \\
\text { Deba }\end{array}$ & & \\
\hline 8. & $\begin{array}{l}\text { Adamawa/ } \\
\text { Taraba }\end{array}$ & Gujba (Mutai) & Not yet quantified & $\begin{array}{l}\text { Deposits in River } \\
\text { Channel }\end{array}$ \\
\hline 9. & Yobe & $\begin{array}{l}\text { Ngala, Marte, Mongunu, } \\
\text { Damboa }\end{array}$ & & Black cotton \\
\hline 10. & Borno & $\begin{array}{l}\text { Gamboru, Marte, Ngala, } \\
\text { Dikwa, Monguno }\end{array}$ & 700 million & $\begin{array}{l}\text { Product of Clay of } \\
\text { quaternary and } \\
\text { tertiary }\end{array}$ \\
\hline 11. & Edo & $\begin{array}{l}\text { Akoko-Edo, Afuze, } \\
\text { Okpebhio, Esan, Owan, } \\
\text { Etsako }\end{array}$ & & \\
\hline 12. & Kebbi & Jega & Not quantified yet & $\begin{array}{l}\text { Found in Benin } \\
\text { formation }\end{array}$ \\
\hline 13. & Delta & Abbi, Amai & & \\
\hline
\end{tabular}

Nigeria is a major oil producer and therefore embarks on substantial drilling activities. With the increasing demand on the use of "local content" in the oil industry by the federal government of Nigeria, and the expensive nature of foreign clay (bentonite), intense search is being conducted for the discovery of new and suitable "local bentonitic clay" which upon beneficiation meet API minimum requirement for oil and gas well drilling mud. 
This is aimed at eradicating the problems created through the importation of foreign bentonite clay and even fosters foreign exchange earnings through export of this local clay.

The aim of this study is to evaluate a local clay sample that can compete favourably with foreign bentonite and meet API minimum numerical standard values for drilling fluid composition. The rheological formulation of the locally sourced bentonite clay sample in substitute for the imported foreign bentonite clay was carried out by the comparative analysis of the parameters of the local mud with the stipulated API standard values to ascertain the level of compliance in drilling operation $^{[1]}$.

\section{Location and Geology of Study Area}

Abbi is located in Ndokwa West Local Government Area of Delta State, Nigeria. It is located within Latitude $6.45^{\circ} \mathrm{E}$ and Longitude $5.30^{\circ} \mathrm{N}$ (figure 1). It consists of several small communities which coexist peacefully. It shares common boundary with Amai in the North, Ogume in the east, Abraka in the West. All these neighbouring towns and communities are marked with appreciable annual rainfall and thick vegetations and hand dug wells which are almost fill to the brim. Abbi on the other hand, experiences heavy rainfall for over six months of the year but is typically grassland with parches of shrubs despite the existence of some swampy zones in the rainy season. Abbi is in a typical Niger Delta region characterized by the Benin, Agbada and Akata formations. It is basically a low land sedimentary region with flat topography in a continental fluid-tide environment characterized by fine whitish top soil underlain by silty formations.

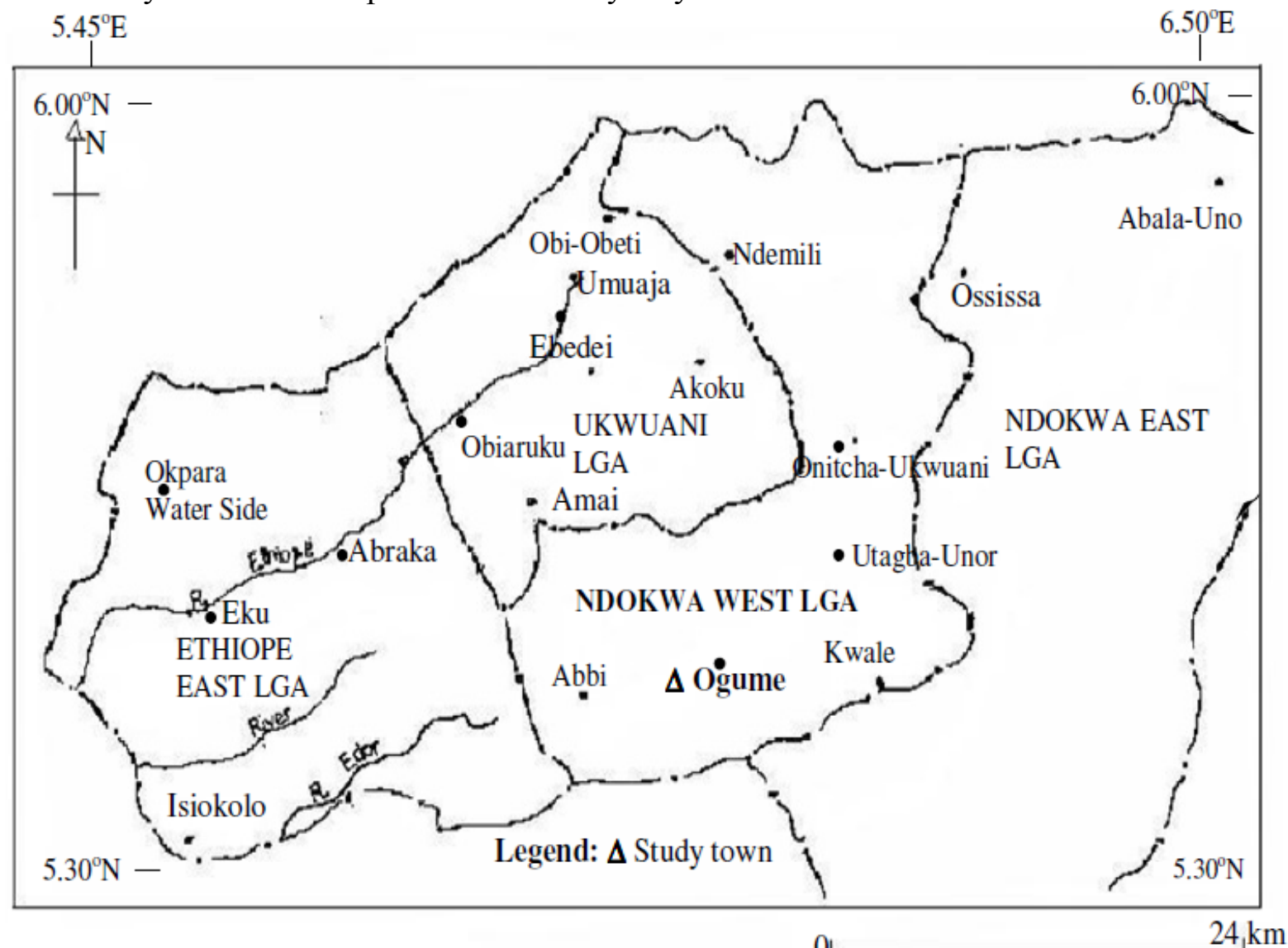

Figure 1: A map showing the area of study

\section{Methodology}

\section{Sample Collection and Sampling Technique}

The improper mode of search and collection of sample that is not a true representation of the clay desired has led to inadequate and improper results and failures. This can be due to inadequate sample collection; sampling technique and testing. Hence some viable clay has been declared 
unviable. A limitation to appropriate clay collection is the depth at which the sample is collected. Sample collected from shallow or weathered depths that have lost such base elements as sodium, calcium and magnesium will give poor results. Because of these facts, the clay sample used for this study was collected at the appropriate depth of about $5 \mathrm{ft}$ and at appropriate horizontal strata where sodium, calcium and magnesium base elements tend to accumulate.

\section{Preparation of Drilling Mud}

The clay sample collected from Abbi was dried under moderate temperature spread out in a plastic tray in a drying oven. The dried clay sample was then subjected to pulverization by pounding it in a mortal. The pulverized clay sample was sieved to obtain fine powdered clay particles.

The sieved clay sample was collected in a beaker and labeled appropriately using a masking tape, then $17.5 \mathrm{~g}, 21.0 \mathrm{~g}$ and $24.5 \mathrm{~g}$ of the fine clay sample was weighed using a spatula into separate mixer cups with the help of weighing balance and labeled appropriately. Afterwards, $350 \mathrm{ml}$ of distilled water is measured using a $500 \mathrm{ml}$ measuring cylinder into the already weighed clay samples.

The mixture of the clay and water was stirred with the aid of multi-beach mixer for (2-5) minutes to obtain homogeneous mixture. The homogeneous mixture obtained was aged for 24 hours for proper hydration. After 24 hours of aging, the mud was re-stirred to re-agitate the mud for characterization.

Where the prepared drilling mud properties do not meet the required standard specifications, certain chemicals are employed for beneficiation of the drilling mud properties.

The weighed sample can be prepared accordingly with the addition of $350 \mathrm{ml}$ of water as indicated below:

$\checkmark$ A high concentration mud contains $24.5 \mathrm{~g}$ of clay plus $350 \mathrm{ml}$ of water

$\checkmark$ Medium concentration mud contains $21.0 \mathrm{~g}$ of clay plus $350 \mathrm{ml}$ of water

$\checkmark$ Low concentration mud contains $17.5 \mathrm{~g}$ of clay plus $350 \mathrm{ml}$ of water

\section{Determination of Drilling Mud Properties}

API RP-13B Standard procedures were employed throughout the laboratory work to determine rheological and fluid loss properties. All the sample mud are based on the formulation of $350 \mathrm{ml}$ of fluid that contains only fresh water.

\section{Determination of Rheological Properties}

This test is done to obtain the Rheological properties of the mud such as viscosity at $600 \mathrm{rpm}$ and $300 \mathrm{rpm}, 10$ minutes and 10 seconds Gel strength, plastic viscosity and yield stress. The equipment used was an OFITE 900 MODEL viscometer while the reagents/materials were freshly prepared sample, masking tape, recording book and biro.

The cord of the viscometer was connected to the power source and the instrument power button switched on. The freshly prepared mud was poured into the sample cup of the viscometer, the ENTER button pressed and the rotor was allowed to rotate for few seconds for stabilization. The rotor sleeve was then immense until the mud touched the scribed line of the rotor sleeve; the mud button was pressed and the viscometer automatically carried out the measurement of the $\theta 600 \mathrm{rpm}$ and $\theta 300 \mathrm{rpm}$. The equipment calculated the 10 seconds and 10 minutes gel strength.

It was observed that at the end of the 10minutes, the machine displayed the value of plastic viscosity (pv), and the yield point (yp) along with 10seconds and 10minutes gel strength were displayed. These values were recorded in the table of result respectively.

\section{pH Determination}

The degree of acidity or alkalinity of mud is indicated by the hydrogen ion concentration, which is commonly expressed in terms of PH. A neutral mud has a PH of 7.0. An alkaline mud has PH readings ranging from just above 7 for slight alkalinity, to 14 for the strongest alkalinity, Acid mud range from just below 7 for slight acidity, to less than I for the strongest acidity. 
PH measurements aid in determining the need for chemical control of the mud, and indicates the presence of contaminates such as cement and gypsum. The appropriate $\mathrm{PH}$ of drilling mud varies with the mud type.

This study used the Multi-Hamilton beach mixer equipment with freshly prepared sample, phydrion dispenser paper,masking tape, recording book and biro as reagents/materials.

As a procedure to determine the $\mathrm{pH}$ of the mud; the freshly prepared mud was re-stirred to obtain homogeneous mixture. About one inch strip of the phydrion dispenser paper was removed and placed gently on the surface of the mud and sufficient time was allowed to elapsed (about few seconds) for the paper to soak up filtrate and change colour. The soaked paper strip was matched with chart on the dispenser from which the strip was taken.

The $\mathrm{pH}$ range of the mud was read and the value recorded in the table of result respectively. The procedure was repeated for other concentration of the mud.

\section{Determination of the Mud Weight}

The mud density test was conducted in order to determine the weight per unit volume of the mud. Mud density must be great enough to provide sufficient hydrostatic heat to prevent influx of formation fluids, but not so great to cause loss of circulation, damage to the drilled formation, or reduce the rate of penetration (ROP). This test is done to determine whether the prepared local mud samples possess API minimum required weight for oil well drilling.

The Multi-Hamilton beach mixer and Bariod mud balance were the equipment used in this study while freshly prepared sample, rag, water, masking tape, recording book and biro were reagents/materials used.

As a procedure to determine the weight of the prepared mud; the instrument base was set up so that it was approximately leveled, the freshly prepared mud was poured into a clean, dried mud balance cup. The lid was placed on the cup and set it firmly but slowly with twisting motion. It was ensured some mud spilled on the outside of the cup through the vent. Then the reading of the mud balance scale is taken and recorded properly against the mud type. The mud cup is then emptied, washed, dried and properly kept away for future use.

It is pertinent to note that the mud weight was higher than that of water because of its density.

\section{Determination of Sand Content}

By definition, solid particles larger than 74 micros (200 meshes) are classified as API sand. (A micron is one (million) inch of a meter there are about 25, 400 microns to an inch) regular determination of the sand content of drilling mud is necessary because these particles can be highly abrasive, and can cause excessive wear of pump parts, drill bits, and pipe connections, excessive sand may also result in the deposition of a thick filter cake on the walls of the hole, or it may settle in the hole around the tools when circulation is temporarily halted, interfering with the operation of drilling tools of settling casing. The sand content test for set is used in the test for sand content determination.

The equipment used was the Bariod sand content set while reagents/materials were freshly prepared sample, rag, water, spatula, masking tape, recording book and biro.

As a procedure to determine the sand content of the prepared mud; the Baroid sand content tube was filled to mark "MUD TO HERE" with the formulated mud sample. Water was then added to the mark "WATER TO HERE", and then the tube was covered with thumb and shaken vigorously.

The mixture of the mud and water was poured out through the screen, the held back sand were carefully washed to ensure that the mud sample was out in a gently running tap. The sand left in the screen was then washed back into the tube through a funnel that is fitted over and inverted slowly into the mouth of the tube. The quantity of the sand that settle in the calibrated tube was then read and recorded as the sand content of the mud in percentage by the volume of mud. 


\section{API Standard Tests and Analysis Values of Drilling Mud}

As mentioned earlier, drilling mud is the mixing or dissolving of bentonite clay in water and addition of other chemicals. When the mud is characterized or tested, the tables recorded down are compared with known standard values.

The American Petroleum Institute (API) standard specification are very important for drilling mud and these specifications are for all the montmorillonite clay family as contained in API practices $13 \mathrm{~A}$ section 5 as presented in appendix A.

\section{Beneficiation of Drilling Mud}

For the prepared mud to be beneficiated it has to be aged and this aging will enable the mixture to hydrate properly and form homogeneous mixture, ready for characterization.

Beneficiation is the treatment of the prepared drilling mud with enhancers such as viscosifiers, weightier polymer, thinners and $\mathrm{pH}$ raiser to improve the fluid properties for enhanced performance. The blending of the additives (beneficiation) can be done wet or dry. Dry blending can be achieved by mixing the dry clay sample with the additives in right proportion to enhance the properties of the mud (i.e. the blend plus water). For wet blending, accurate measurement of dry clay is blended with $350 \mathrm{ml}$ of fresh water and allowed to hydrate. If the wet blend is not adequately hydrated, the mixture will lack homogeneity.

In this study, $1.0 \mathrm{~g}$ of Drispac and $1.0 \mathrm{~g}$ of potash was used for the beneficiation of the sample, to achieve improvement of rheological properties (i.e. viscosity and gel strength) and $\mathrm{pH}$ respectively.

\section{Results and Discussion}

Table 2: Mud Sample without Beneficiation after 24hrs of Aging

\begin{tabular}{|c|c|c|c|c|c|c|c|c|c|c|c|c|}
\hline \multirow{2}{*}{$\begin{array}{l}\text { Clay } \\
\text { conc. in } \\
350 \mathrm{ml} \text { of } \\
\text { water (g) }\end{array}$} & \multirow[t]{2}{*}{$\begin{array}{l}\text { Mud } \\
\text { Weight } \\
\text { (lb/gal) }\end{array}$} & \multicolumn{2}{|c|}{$\begin{array}{l}\text { Viscometer } \\
\text { Reading (cp) }\end{array}$} & \multirow[t]{2}{*}{$\begin{array}{l}\text { Mud } \\
\text { pH }\end{array}$} & \multicolumn{2}{|c|}{$\begin{array}{l}\text { Mud gel } \\
\text { strength } \\
\left(\mathrm{lb} / 100 \mathrm{ft}^{2}\right)\end{array}$} & \multirow[t]{2}{*}{$\begin{array}{l}\text { Mud } \\
\text { sand } \\
\% \text { vol. }\end{array}$} & \multirow[t]{2}{*}{$\begin{array}{l}\text { Mud } \\
\text { PV } \\
\text { (cp) }\end{array}$} & \multirow[t]{2}{*}{$\begin{array}{l}\text { Mud } \\
\text { AV } \\
\text { (cp) }\end{array}$} & \multirow[t]{2}{*}{$\begin{array}{l}\text { Mud YP } \\
\left(\mathrm{lb} / 100 \mathrm{ft}^{2}\right)\end{array}$} & \multirow[t]{2}{*}{$\begin{array}{l}\text { "n" } \\
\text { factor }\end{array}$} & \multirow[t]{2}{*}{$\begin{array}{l}\text { "k" } \\
\text { factor } \\
@ 511\end{array}$} \\
\hline & & $\stackrel{(a)}{600}$ & $\begin{array}{c}(a) \\
300\end{array}$ & & $10 \mathrm{~s}$ & $10 m$ & & & & & & \\
\hline 17.5 & 8.60 & 2.40 & 1.70 & 6.0 & 0.00 & 0.00 & 0.25 & 0.7 & 1.2 & 1.0 & 0.50 & 1.24 \\
\hline 21.0 & 8.60 & 2.60 & 2.00 & 6.0 & 0.80 & 0.80 & 0.25 & 0.6 & 1.3 & 1.4 & 0.38 & 0.94 \\
\hline 24.5 & 8.60 & 2.70 & 2.00 & 6.0 & 0.90 & 1.00 & 0.38 & 0.7 & 1.4 & 1.3 & 0.43 & 0.54 \\
\hline
\end{tabular}

Table 3: Mud Sample with Beneficiation after 24hrs of Aging Using 1.0g Drispac and 1.0g Potash

\begin{tabular}{|c|c|c|c|c|c|c|c|c|c|c|c|c|}
\hline \multirow{2}{*}{$\begin{array}{l}\text { Clay } \\
\text { conc. in } \\
350 \mathrm{ml} \text { of } \\
\text { water }(\mathrm{g})\end{array}$} & \multirow[t]{2}{*}{$\begin{array}{l}\text { Mud } \\
\text { Weight } \\
\text { (lb/gal) }\end{array}$} & \multicolumn{2}{|c|}{$\begin{array}{l}\text { Viscometer } \\
\text { Reading (cp) }\end{array}$} & \multirow[t]{2}{*}{$\begin{array}{l}\text { Mud } \\
\mathrm{pH}\end{array}$} & \multicolumn{2}{|c|}{$\begin{array}{l}\text { Mud gel } \\
\text { strength } \\
\left(\mathrm{lb} / 100 \mathrm{ft}^{2}\right)\end{array}$} & \multirow[t]{2}{*}{$\begin{array}{l}\text { Mud } \\
\text { sand } \\
\% \text { vol. }\end{array}$} & \multirow[t]{2}{*}{$\begin{array}{l}\text { Mud } \\
\text { PV } \\
\text { (cp) }\end{array}$} & \multirow[t]{2}{*}{$\begin{array}{l}\text { Mud } \\
\text { AV } \\
\text { (cp) }\end{array}$} & \multirow[t]{2}{*}{$\begin{array}{l}\text { Mud YP } \\
\left(\mathrm{lb} / 100 \mathrm{ft}^{2}\right)\end{array}$} & \multirow[t]{2}{*}{$\begin{array}{l}\text { "n" } \\
\text { factor }\end{array}$} & \multirow[t]{2}{*}{$\begin{array}{l}\text { "k" } \\
\text { factor } \\
\text { a, } 511\end{array}$} \\
\hline & & $\underset{600}{a}$ & $\underset{300}{a}$ & & $10 \mathrm{~s}$ & $10 m$ & & & & & & \\
\hline 17.5 & 8.60 & 33.00 & 20.90 & 12.0 & 0.30 & 0.40 & 0.25 & 14.6 & 17.8 & 6.3 & 0.76 & 1.58 \\
\hline 21.0 & 8.70 & 33.20 & 19.00 & 12.0 & 0.30 & 0.40 & 0.25 & 14.2 & 16.6 & 4.8 & 0.80 & 1.15 \\
\hline 24.5 & 8.70 & 35.50 & 18.90 & 12.0 & 0.50 & 0.60 & 0.38 & 14.1 & 16.5 & 4.8 & 0.80 & 1.14 \\
\hline
\end{tabular}

Table 4: Bentonite Mud without Beneficiation after 24hrs of Aging

\begin{tabular}{|c|c|c|c|c|c|c|c|c|c|c|c|c|}
\hline \multirow{2}{*}{$\begin{array}{l}\text { Clay } \\
\text { conc. } \\
350 \mathrm{ml} \text { of } \\
\text { water }(\mathrm{g})\end{array}$} & \multirow[t]{2}{*}{$\begin{array}{l}\text { Mud } \\
\text { Weight } \\
\text { (lb/gal) }\end{array}$} & \multicolumn{2}{|c|}{$\begin{array}{l}\text { Viscometer } \\
\text { Reading (cp) }\end{array}$} & \multirow[t]{2}{*}{$\begin{array}{l}\text { Mud } \\
\text { pH }\end{array}$} & \multicolumn{2}{|c|}{$\begin{array}{l}\text { Mud gel } \\
\text { strength } \\
\left(\mathrm{lb} / 100 \mathrm{ft}^{2}\right)\end{array}$} & \multirow[t]{2}{*}{$\begin{array}{l}\text { Mud } \\
\text { sand } \\
\% \text { vol. }\end{array}$} & \multirow[t]{2}{*}{$\begin{array}{l}\text { Mud } \\
\text { PV } \\
\text { (cp) }\end{array}$} & \multirow[t]{2}{*}{$\begin{array}{l}\text { Mud } \\
\text { AV } \\
\text { (cp) }\end{array}$} & \multirow[t]{2}{*}{$\begin{array}{l}\text { Mud YP } \\
\left(\mathrm{lb} / 100 \mathrm{ft}^{2}\right)\end{array}$} & \multirow[t]{2}{*}{$\begin{array}{l}\text { "n" } \\
\text { factor }\end{array}$} & \multirow[t]{2}{*}{$\begin{array}{l}\text { "k" } \\
\text { factor } \\
@ 511\end{array}$} \\
\hline & & $\stackrel{9}{600}$ & $\begin{array}{c}\text { a } \\
300\end{array}$ & & $10 \mathrm{~s}$ & $10 \mathrm{~m}$ & & & & & & \\
\hline 17.5 & 8.70 & 17.70 & 10.20 & 9.0 & 0.10 & 1.50 & 0.30 & 7.5 & 8.9 & 2.7 & 0.79 & 0.65 \\
\hline 21.0 & 8.70 & 21.10 & 11.60 & 9.0 & 0.20 & 5.10 & 0.30 & 9.5 & 10.6 & 2.1 & 0.56 & 3.27 \\
\hline 24.5 & 8.70 & 31.40 & 18.50 & 9.0 & 0.70 & 12.10 & 0.30 & 12.9 & 15.7 & 5.6 & 0.76 & 1.39 \\
\hline
\end{tabular}


Table 5: Bentonite Mud with Beneficiation after 24hrs of aging Using 1.0g Drispac and 1.0g Potash

\begin{tabular}{|c|c|c|c|c|c|c|c|c|c|c|c|c|}
\hline \multirow{2}{*}{$\begin{array}{l}\text { Clay } \\
\text { conc. in } \\
350 \mathrm{ml} \text { of } \\
\text { water }(\mathrm{g})\end{array}$} & \multirow[t]{2}{*}{$\begin{array}{l}\text { Mud } \\
\text { Weight } \\
\text { (lb/gal) }\end{array}$} & \multicolumn{2}{|c|}{$\begin{array}{l}\text { Viscometer } \\
\text { Reading (cp) }\end{array}$} & \multirow[t]{2}{*}{$\begin{array}{l}\text { Mud } \\
\mathrm{pH}\end{array}$} & \multicolumn{2}{|c|}{$\begin{array}{l}\text { Mud gel } \\
\text { strength } \\
\left(1 \mathrm{~b} / 100 \mathrm{ft}^{2}\right)\end{array}$} & \multirow[t]{2}{*}{$\begin{array}{l}\text { Mud } \\
\text { sand } \\
\text { \%vol. }\end{array}$} & \multirow[t]{2}{*}{$\begin{array}{l}\text { Mud } \\
\text { PV } \\
\text { (cp) }\end{array}$} & \multirow[t]{2}{*}{$\begin{array}{l}\text { Mud } \\
\text { AV } \\
\text { (cp) }\end{array}$} & \multirow[t]{2}{*}{$\begin{array}{l}\text { Mud YP } \\
\left(\mathrm{lb} / 100 \mathrm{ft}^{2}\right)\end{array}$} & \multirow[t]{2}{*}{$\begin{array}{l}\text { "n" } \\
\text { factor }\end{array}$} & \multirow[t]{2}{*}{$\begin{array}{l}\text { "k" } \\
\text { factor } \\
\text { (a) } 511\end{array}$} \\
\hline & & $\underset{600}{a}$ & $\underset{300}{a}$ & & $10 s$ & $10 m$ & & & & & & \\
\hline 17.5 & 8.90 & 246.1 & 156.4 & 9.5 & 30.20 & 41.50 & 0.30 & 89.7 & 123 & 66.7 & 0.65 & 21.80 \\
\hline 21.0 & 8.70 & 287.2 & 160.2 & 9.5 & 38.30 & 59.10 & 0.30 & 127 & 146 & 33.2 & 0.84 & 7.77 \\
\hline 24.5 & 8.70 & 300.0 & 179.3 & 9.5 & OR & OR & 0.30 & OR & OR & OR & OR & OR \\
\hline
\end{tabular}

*OR-out-of-range

Table 6: Comparison of Mud Properties with API Numerical Value Specification (17.5g)

\begin{tabular}{|c|c|c|c|c|c|c|c|c|}
\hline & \multirow{2}{*}{$\begin{array}{l}\text { Mud } \\
\text { weight } \\
\text { (lb/gal) }\end{array}$} & \multirow[t]{2}{*}{$\begin{array}{l}\mathrm{pH} \\
\text { level }\end{array}$} & \multicolumn{2}{|c|}{$\begin{array}{l}\text { Viscometer } \\
\text { Reading (cp) }\end{array}$} & \multicolumn{2}{|c|}{$\begin{array}{l}\text { Mud gel strength } \\
\left(\mathrm{lb} / 100 \mathrm{ft}^{2}\right)\end{array}$} & \multirow{2}{*}{$\begin{array}{l}\text { Sand } \\
\text { content } \\
\% \text { volume }\end{array}$} & \multirow[t]{2}{*}{ "n" factor } \\
\hline & & & $\stackrel{@}{600}$ & $\begin{array}{c}0 \\
300\end{array}$ & $10 \operatorname{secs}$ & $10 \mathrm{mins}$ & & \\
\hline $\begin{array}{l}\text { API numerical } \\
\text { value } \\
\text { specification } \\
\text { (minimum) }\end{array}$ & 8.65 & 9.5 & 30.0 & 30 & & & & \\
\hline $\begin{array}{l}\text { Sample mud } \\
\text { before } \\
\text { beneficiation } \\
(17.5 \mathrm{~g})\end{array}$ & 8.60 & 6.0 & 2.40 & 1.70 & 0.00 & 0.00 & 0.25 & 0.50 \\
\hline $\begin{array}{l}\text { Foreign mud } \\
(17.5 \mathrm{~g})\end{array}$ & 8.70 & 9.0 & 17.0 & 10.20 & 0.10 & 1.50 & 0.30 & 0.79 \\
\hline $\begin{array}{l}\text { Sample mud } \\
\text { after } \\
\text { beneficiation } \\
(17.5 \mathrm{~g})\end{array}$ & 8.60 & 12.0 & 33.0 & 20.90 & 0.30 & 0.40 & 0.25 & 0.76 \\
\hline $\begin{array}{l}\text { API numerical } \\
\text { value } \\
\text { specification } \\
\text { (maximum) }\end{array}$ & 9.00 & 12.5 & & & & & 1.0 & 1.0 \\
\hline
\end{tabular}

From table 6 , the mud weight of the $19.5 \mathrm{~g}$ clay concentration of sample mud was $8.60 \mathrm{lb} / \mathrm{gal}$ before beneficiation took place. This is a little short of API minimum numerical value standard $(8.65 \mathrm{lb} / \mathrm{gal})$. The mud weight of the foreign bentonite sample was $8.70 \mathrm{lb} / \mathrm{gal}$. While on beneficiation with both $1.0 \mathrm{~g}$ Drispac and $1.0 \mathrm{~g}$ potash the sample mud weight remained constant at $8.60 \mathrm{lb} / \mathrm{gal}$ this is due to the fact that it's a low concentration mud.

From table 6 , the mud $\mathrm{pH}$ of the $19.5 \mathrm{~g}$ clay concentration sample mud was 6.0 before beneficiation took place. This showed that the sample mud was a little acidic and hence fell short of API minimum numerical value standard (i.e. 9.5). The $\mathrm{pH}$ value of the foreign bentonite mud sample was found to be 9.0. While on beneficiation with $1.0 \mathrm{~g}$ potash, the sample mud $\mathrm{pH}$ increased from 6.0 to 12.0 which then conformed to API numerical value specifications (i.e. 9.5-12.5). From table 6, the viscometer reading of the 19.5g clay concentration sample mud @600rpm was $1.70 \mathrm{cp}$, this is a far cry from the $30 \mathrm{cp}$ API minimum numerical value standard for drilling mud. This showed that the viscosity of our local sample mud is very low. The viscometer reading for the foreign mud sample was $17.0 \mathrm{cp}$. While on beneficiation with $1.0 \mathrm{~g}$ Drispac, the mud sample viscometer readings improved from $2.40 \mathrm{cp}$ to $33 \mathrm{cp}$. 
The gel strength@10mins also increased from $0.0 \mathrm{lb} / 100 \mathrm{ft}^{2}$ to $0.4 \mathrm{lb} / 100 \mathrm{ft}^{2}$ when it was beneficiated with $1.0 \mathrm{~g}$ of Drispac.

From table 6 , the sand content of the $19.5 \mathrm{~g}$ clay concentration local sample clay mud was constant at a value of $0.25 \%$ which was within API numerical value standard of between $0.3 \%$ $1.0 \%$. The sand content of the foreign bentonite mud sample was $0.3 \%$

From the table 6 , the " $n$ "- factor value for the $19.5 \mathrm{~g}$ clay concentration sample mud was 0.50 . Upon beneficiation with $1.0 \mathrm{~g}$ Drispac, the value increased from 0.50 to 0.76 . The value for the " $n$ "factor for the foreign bentonite clay mud was 0.79 .

Table 7: Comparison of Mud Properties with API Numerical Value Specification (21.0g)

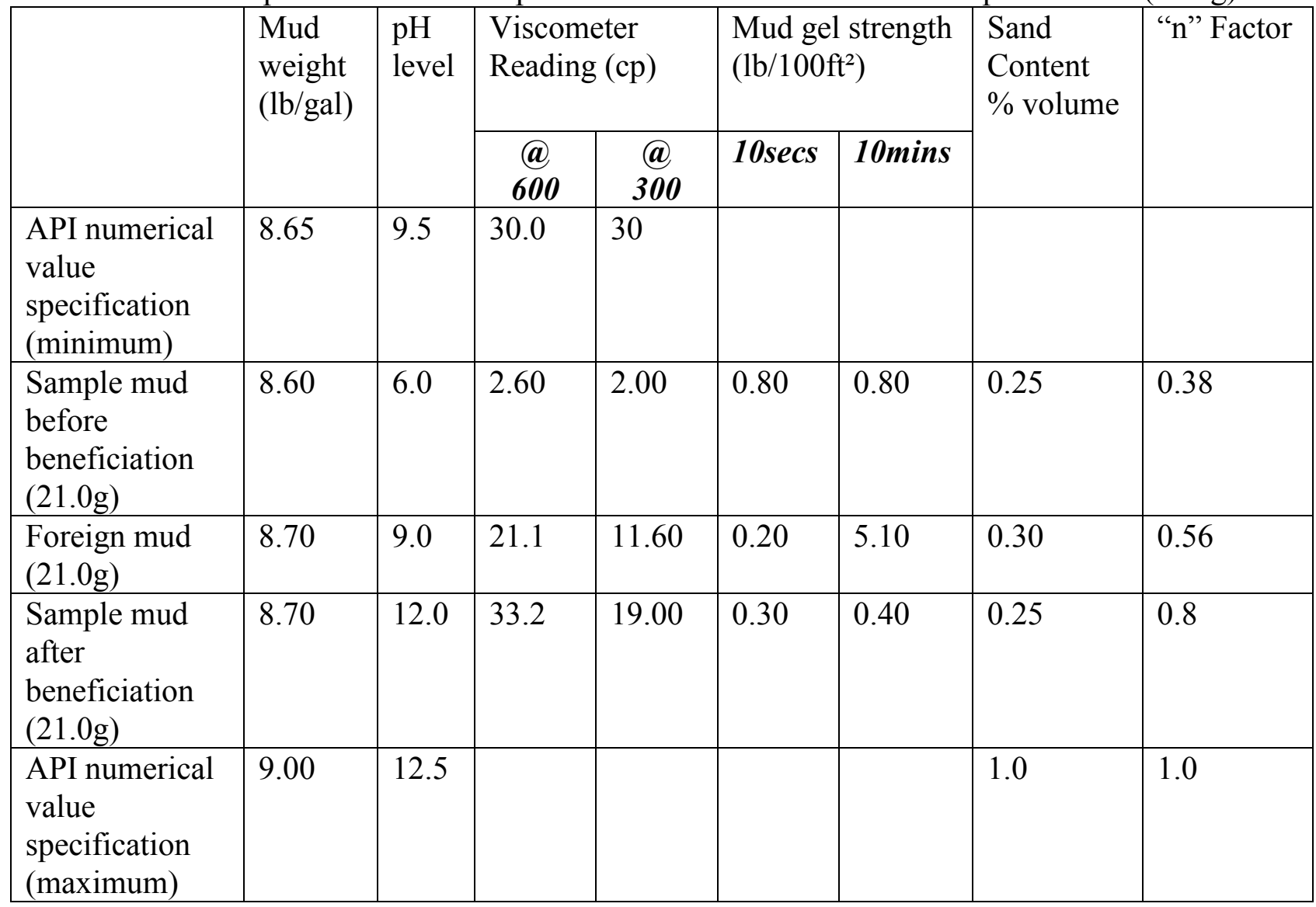

From table 7 , the mud weight of the $21.0 \mathrm{~g}$ clay concentration of sample mud was $8.60 \mathrm{lb} / \mathrm{gal}$ before beneficiation took place. This is a little short of API minimum numerical value standard $(8.65 \mathrm{lb} / \mathrm{gal})$. The mud weight of the foreign bentonite sample was $8.70 \mathrm{lb} / \mathrm{gal}$. While on beneficiation with both $1.0 \mathrm{~g}$ Drispac and $1.0 \mathrm{~g}$ potash the sample mud weight increased from $8.60 \mathrm{lb} /$ gal to $8.70 \mathrm{lb} /$ gal which now fell within API numerical value standard for drilling mud (i.e. $8.65 \mathrm{lb} /$ gal-9.60lb/gal).

From table 7 , the mud $\mathrm{pH}$ of the $21.0 \mathrm{~g}$ clay concentration sample mud was 6.0 before beneficiation took place. This showed that the sample mud was a little acidic and hence fell short of API minimum numerical value standard (i.e. 9.5). The $\mathrm{pH}$ value of the foreign bentonite mud sample was found to be 9.0. While on beneficiation with $1.0 \mathrm{~g}$ potash, the sample mud $\mathrm{pH}$ increased from 6.0 to 12.0 which then conformed to API numerical value specifications (i.e. 9.5-12.5).

From table 7, the viscometer reading of the $21.0 \mathrm{~g}$ clay concentration sample mud @600rpm was $2.60 \mathrm{cp}$, this is a far cry from the $30 \mathrm{cp}$ API minimum numerical value standard for drilling mud. This showed that the viscosity of our local sample mud is very low. The viscometer reading for the foreign mud sample was $21.1 \mathrm{cp}$. While on beneficiation with $1.0 \mathrm{~g}$ Drispac, the mud sample viscometer readings improved from $2.60 \mathrm{cp}$ to $33.20 \mathrm{cp}$. 
The gel strength@10mins also decreased from $0.8 \mathrm{lb} / 100 \mathrm{ft}^{2}$ to $0.4 \mathrm{lb} / 100 \mathrm{ft}^{2}$ when it was beneficiated with 1.0g of Drispac.

From table 7 , the sand content of the $21.0 \mathrm{~g}$ clay concentration local sample clay mud was constant at a value of $0.25 \%$ which was within API numerical value standard of between $0.3 \%$ $1.0 \%$. The sand content of the foreign bentonite mud sample was $0.3 \%$.

From the table 7 , the " $n$ "- factor value for the $21.0 \mathrm{~g}$ clay concentration sample mud was 0.38 . Upon beneficiation with $1.0 \mathrm{~g}$ Drispac, the value increased from 0.38 to 0.80 . The value for the " $\mathrm{n}$ "factor for the foreign bentonite clay mud was 0.56 .

Table 8: Comparison of Mud Properties with API Numerical Value Specification (24.5g)

\begin{tabular}{|c|c|c|c|c|c|c|c|c|}
\hline & \multirow{2}{*}{$\begin{array}{l}\text { Mud } \\
\text { weight } \\
\text { (lb/gal) }\end{array}$} & \multirow[t]{2}{*}{$\begin{array}{l}\mathrm{pH} \\
\text { level }\end{array}$} & \multicolumn{2}{|c|}{$\begin{array}{l}\text { Viscometer } \\
\text { Reading (cp) }\end{array}$} & \multicolumn{2}{|c|}{$\begin{array}{l}\text { Mud gel strength } \\
\left(\left(\mathrm{lb} / 100 \mathrm{ft}^{2}\right)\right.\end{array}$} & \multirow{2}{*}{$\begin{array}{l}\text { Sand } \\
\text { Content } \\
\% \text { volume }\end{array}$} & \multirow[t]{2}{*}{ "n" factor } \\
\hline & & & $\underset{600}{0}$ & $\begin{array}{c}@ \\
300\end{array}$ & 10secs & $10 \mathrm{mins}$ & & \\
\hline $\begin{array}{l}\text { API numerical } \\
\text { value } \\
\text { specification } \\
\text { (minimum) }\end{array}$ & 8.65 & 9.5 & 30.0 & 30 & & & & \\
\hline $\begin{array}{l}\text { Sample mud } \\
\text { before } \\
\text { beneficiation } \\
(24.5 \mathrm{~g})\end{array}$ & 8.60 & 6.0 & 2.70 & 2.00 & 0.90 & 1.00 & 0.38 & 0.43 \\
\hline $\begin{array}{l}\text { Foreign mud } \\
(24.5 \mathrm{~g})\end{array}$ & 8.70 & 9.0 & 31.4 & 18.50 & 0.70 & 12.10 & 0.30 & 0.76 \\
\hline $\begin{array}{l}\text { Sample mud } \\
\text { after } \\
\text { beneficiation } \\
(24.5 \mathrm{~g})\end{array}$ & 8.70 & 12.0 & 35.5 & 18.90 & 0.50 & 0.60 & 0.38 & 0.80 \\
\hline $\begin{array}{l}\text { API numerical } \\
\text { value } \\
\text { specification } \\
\text { (maximum) }\end{array}$ & 9.00 & 12.5 & & & & & 1.0 & 1.0 \\
\hline
\end{tabular}

For analysis of mud weight from table 8 , the mud weight of the $24.5 \mathrm{~g}$ clay concentration of sample mud was $8.60 \mathrm{lb} /$ gal before beneficiation took place. This is a little short of API minimum numerical value standard $(8.65 \mathrm{lb} / \mathrm{gal})$. The mud weight of the foreign bentonite sample was $8.701 \mathrm{~b} /$ gal. While on beneficiation with both $1.0 \mathrm{~g}$ Drispac and $1.0 \mathrm{~g}$ potash the sample mud weight increased from $8.601 \mathrm{~b} /$ gal to $8.70 \mathrm{lb} / \mathrm{gal}$ which now fell within API numerical value standard for drilling mud (i.e. $8.65 \mathrm{lb} /$ gal-9.60lb/gal).

For analysis of mud $\mathrm{pH}$ from table 8 , the mud $\mathrm{pH}$ of the $24.5 \mathrm{~g}$ clay concentration sample mud was 6.0 before beneficiation took place. This showed that the sample mud was a little acidic and hence fell short of API minimum numerical value standard (i.e. 9.5). The $\mathrm{pH}$ value of the foreign bentonite mud sample was found to be 9.0. While on beneficiation with $1.0 \mathrm{~g}$ potash, the sample mud $\mathrm{pH}$ increased from 6.0 to 12.0 which then conformed to API numerical value specifications (i.e. 9.5-12.5).

For rheological properties analysis, from table 8 , the viscometer reading of the $24.5 \mathrm{~g}$ clay concentration sample mud @600rpm was $2.70 \mathrm{cp}$, this is a far cry from the $30 \mathrm{cp}$ API minimum numerical value standard for drilling mud. This showed that the viscosity of our local sample mud is very low. The viscometer reading for the foreign mud sample was $31.4 \mathrm{cp}$. While on beneficiation with $1.0 \mathrm{~g}$ Drispac, the mud sample viscometer readings improved from $2.70 \mathrm{cp}$ to $35.50 \mathrm{cp}$. 
The gel strength@10mins also decreased from $1.0 \mathrm{lb} / 100 \mathrm{ft}^{2}$ to $0.6 \mathrm{lb} / 100 \mathrm{ft}^{2}$ when it was beneficiated with 1.0g of Drispac.

For sand content analysis from table 8 , the sand content of the $24.5 \mathrm{~g}$ clay concentration local sample clay mud was constant at a value of $0.38 \%$ which was within API numerical value standard of between $0.3 \%-1.0 \%$. The sand content of the foreign bentonite mud sample was $0.3 \%$.

For power law index analysis from the table 8, the " $n$ "- factor value for the $24.5 \mathrm{~g}$ clay concentration sample mud was 0.43 . Upon beneficiation with $1.0 \mathrm{~g}$ Drispac, the value increased from 0.43 to 0.80 . The value for the " $n$ "- factor for the foreign bentonite clay mud was 0.76 .

\section{Conclusion}

From the above analysis, it was obvious that most of the parameters of the local clay mud such as: sand content, consistency index and power law index met the minimum required specification. While others such as: rheological properties, mud $\mathrm{pH}$ and mud weight needed little treatment with additives for favorable comparison with API standard for drilling fluid.

Local clay sample was successfully treated with readily available additives to improve its properties to meet API minimum specifications.

A significant economic opportunity exists for large scale production of local clay in formulating drilling mud. But the clay must however be acquired at the right depth and strata to ensure good laboratory response to treatment.

\section{Recommendation}

Nigerian vision 2020 drive which is aimed at making Nigeria one of the developed nations in the world is dependent mainly on the aggressive development of the Oil and Gas Industry (mainstay of the nation's economy) which could be achieved with the use of local content. The drilling mud, which is used in oil well drilling has significant role to play in actualization of this dream and hence its market cost should be as low as possible. This can be achieved by sourcing for local clay, processing and treating them to meet up with API standard specification as was done in this project.

Based on our findings, Abbi clay showed market susceptibility to treatment with very low sand content, if properly sampled from the right depth and strata the clay will make a better mud making clay. This project recommends that the:

Federal Government of Nigeria, the major oil companies and stake holders should encourage large scale production and utilization of the local clay for formulation of drilling mud if we must meet our target of becoming one of the top economic countries of the world in the year 2020 .

Encourage further research to discover local additives that can be used to replace the foreign ones used in this research study.

\section{Appendix}

Appendix A: API Standard Numerical Value Requirement for Drilling Fliuds

\begin{tabular}{|l|l|}
\hline Drillling Fluid Property & Numerical Value Requirement \\
\hline Mud density (lb/gal) & $8.65-9.60$ \\
\hline Viscometer dial reading @600rpm & $30 \mathrm{cp}$ \\
\hline Plastic viscosity (cp) & $8-10$ \\
\hline Yield point (Ib/100ft2) & $3 \times$ plastic viscosity \\
\hline Fluid loss (Water) & $15.0 \mathrm{ml}$ maximum \\
\hline pH level & $9.5 \mathrm{~min}-12.5 \mathrm{max}$ \\
\hline
\end{tabular}




\begin{tabular}{|l|l|}
\hline Sand content & $(1-2) \%$ maximum \\
\hline Screen analysis & 4 (maximum) \\
\hline Moisture content & $10 \%$ (maximum) \\
\hline Ca + (ppm) & 2.50 (maximum) \\
\hline Marsh funnel viscosity & $52-56 \mathrm{sec} / \mathrm{q}+$ \\
\hline Mud yield (bbi/ton) & 91 (maximum) \\
\hline API filtrate (ml) & 30 (minimum) \\
\hline Montmorillonite & $70-130$ \\
\hline Vermiculite & $100-200$ \\
\hline Illite & $10-40$ \\
\hline Kadinite & $3-15$ \\
\hline Chlorite & $10-40$ \\
\hline Marsh funnel viscosity for water & 26 sec/q+ \pm 0 \\
\hline N-Factor (power law index) & 1 (maximum) \\
\hline Yp/pv ratio & 3.0 (maximum) \\
\hline
\end{tabular}

\section{References}

[1]. A. Abdulkadir, L.A. Osawemwenze, G.M. Adogbo, Rheological and Filtration Properties of Kaolinite Based Drilling Mud, International Journal of Scientific and Engineering Research. 4(7) (2013) 2214-2220.

[2]. T. U. Apugo-Nwosu et al, Studies on the Suitability of Ubakala Bentonitic Clay for Oil Well Drilling Mud Formation, British J. Appl. Sci. Technol. 1(4) (2011) 152.

[3]. W.A. Dear, R.A. Howie, J. Zussaman, Introduction to Rock-forming Mineral, ELBS/Longman Essex England. (1989) 252-269.

[4]. O.O James et al, Beneficiation and Characterisation of A Bentonite From North-Eastern Nigeria, Journal of the North Carolina Academy of Science. 124(4) (2008) 154-158.

[5]. E.B. Nelson, Well Cementing, Elsevier, New York, 1990.

[6]. A.B. Oriji, F.S. Lawal, Z. Bala, Evaluating the Efficiency of Nigerian Local Bentonite as an Extender in Oil Well Cementation, Chemical and Process Engineering Research. 28 (2014).

[7]. O.Omole et al, Investigation into the Rheological and Filtration Properties of Drilling Mud Formulated with Clays from Northern Nigeria, Journal of Petroleum and Gas Engineering. 4(1) (2013) 1-7.

[8]. B. Velde, Introduction to clay minerals. Chapman and Hall, London, 1992, pp. 1-165.

[9]. H. Rabia, Well Engineering and Constructions, Entrac Consulting, Netherland, 2001.

[10]. H. Rabia, Well Engineering and Constructions, Entrac Consulting, Netherland, 2002. 